\title{
Teaching NeuroImages: Waardenburg syndrome type 2
}

Marcos Rosa Júnior, MD, PhD, Larissa Marques Santana, MD, Bernardo Faria Ramos, MD, PhD, and Henrique Faria Ramos, MD, PhD

Neurology ${ }^{\circledR}$ 2019;92:e1935-e1936. doi:10.1212/WNL.0000000000007318
Correspondence

Dr. Rosa Júnior

marcosrosajr@hotmail.com

Figure 1 Vivid blue eyes

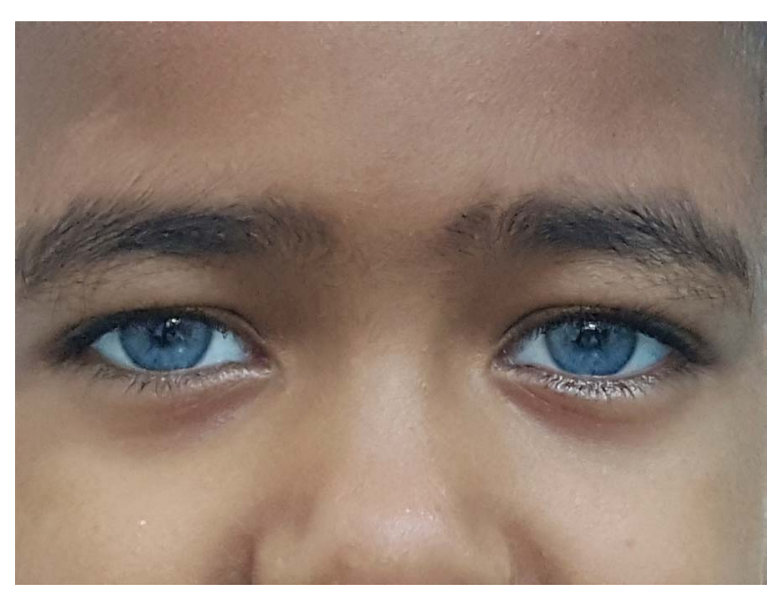

Bilateral isohypochromia iridis (vivid blue eyes) in our patient.

A 5-year-old boy presented with bilateral congenital sensorineural hearing loss and bilateral isohypochromia iridis without dystopia canthorum. MRI showed a shortened posterior semicircular canal (figures 1 and 2) compatible with Waardenburg syndrome (WS).

WS is a rare genodermatosis that affects 1:40,000 children and is caused by abnormal migration of melanoblasts from the neuroectoderm. There are 4 types of WS ( 1 and 3, autosomal dominant; 2 and 4, dominant or recessive). Type 2 differs from type 1 due to the absence of dystopia canthorum. Type 3 is associated with musculoskeletal abnormalities and type 4 with Hirschsprung disease. ${ }^{1,2}$

\section{Author contributions}

M. Rosa Júnior: design or conceptualization of the study, analysis or interpretation of the data, drafting or revising the manuscript for intellectual content. L.M. Santana: analysis or interpretation of the data. B.F. Ramos: analysis or interpretation of the data, drafting or revising the manuscript for intellectual content. H.F. Ramos: analysis or interpretation of the data, drafting or revising the manuscript for intellectual content.

\section{Study funding}

No targeted funding reported.

\section{Disclosure}

The authors report no disclosures relevant to the manuscript. Go to Neurology.org/N for full disclosures.

\section{MORE ONLINE}

\section{$\rightarrow$ Teaching slides}

links.lww.com/WNL/

A860

From the Departments of Neuroradiology (M.R.J.), Radiology (L.M.S.), and Otorhinolaryngology (B.F.R., H.F.R.), Hospital Universitário Cassiano Antônio de Moraes da Universidade Federal do Espírito Santo-HUCAM/UFES/EBSERH, Vitória ES, Brazil.

Go to Neurology.org/N for full disclosures. 
Figure $2 \mathrm{MRI}$ in Waardenburg syndrome

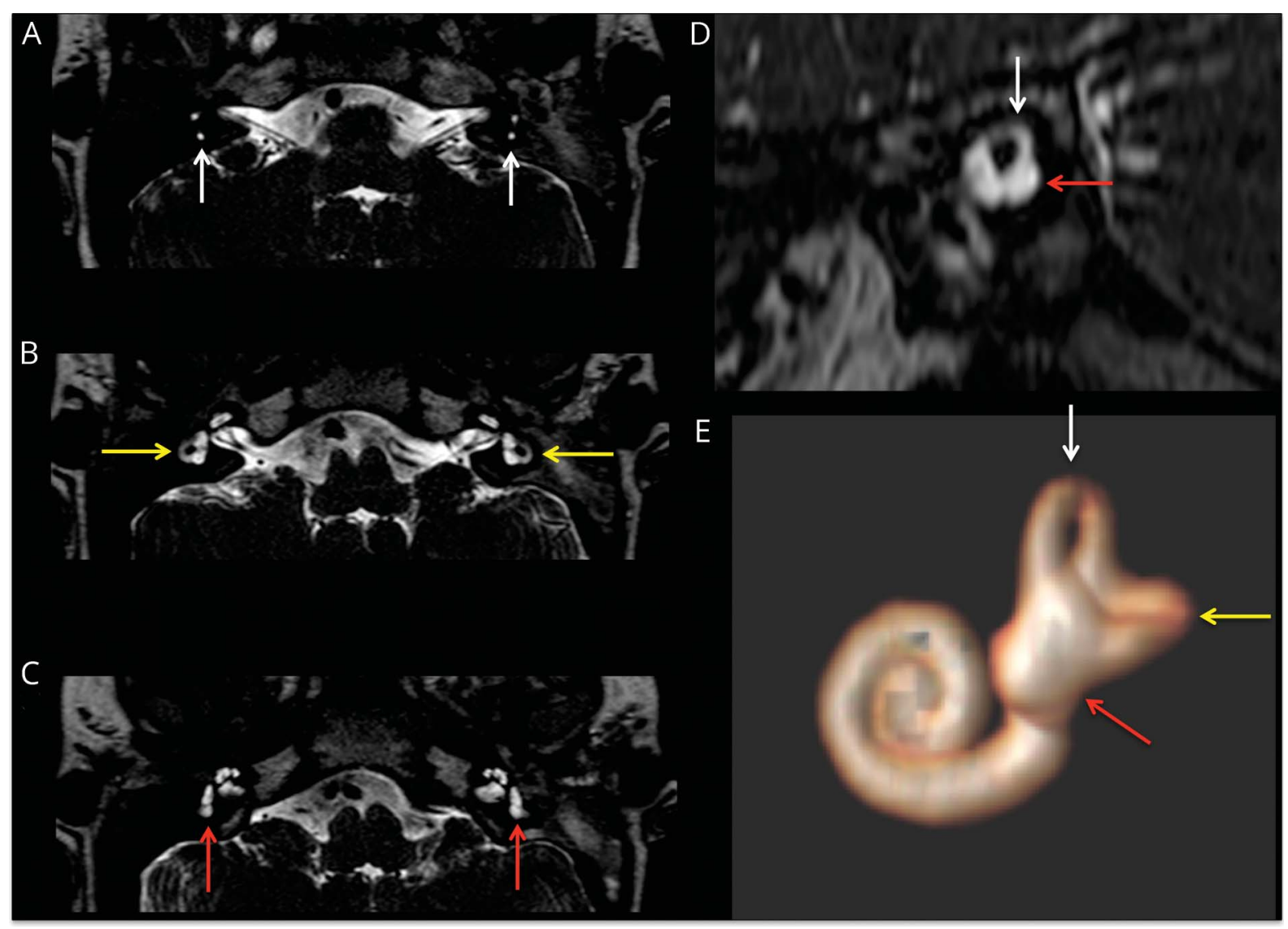

(A-C) Axial T2-weighted imaging (T2WI) shows normal superior semicircular canal (SC) (white arrows), normal lateral SC (yellow arrows), and shortened and thick posterior SC (red arrows). (D) Sagittal T2WI and (E) 3D posterior view show normal superior SC (white arrow) and abnormal posterior SC (red arrow).

\section{References}

1. Read AP, Newton VE. Waardenburg syndrome. J Med Genet 1997;34:656-665.
2. Soni CR, Kumar G. Child Neurology: a patient with dissimilar eye color and deafness. Neurology 2010;74:e25-e26. 


\section{Neurology}

\section{Teaching NeuroImages: Waardenburg syndrome type 2}

Marcos Rosa Júnior, Larissa Marques Santana, Bernardo Faria Ramos, et al. Neurology 2019;92;e1935-e1936

DOI 10.1212/WNL.0000000000007318

\section{This information is current as of April 15, 2019}

\section{Updated Information \& Services}

References

Subspecialty Collections

Permissions \& Licensing

Reprints including high resolution figures, can be found at: http://n.neurology.org/content/92/16/e1935.full

This article cites 2 articles, 2 of which you can access for free at: http://n.neurology.org/content/92/16/e1935.full\#ref-list-1

This article, along with others on similar topics, appears in the following collection(s):

\section{Audition}

http://n.neurology.org/cgi/collection/audition MRI

http://n.neurology.org/cgi/collection/mri

Information about reproducing this article in parts (figures,tables) or in its entirety can be found online at:

http://www.neurology.org/about/about_the_journal\#permissions

Information about ordering reprints can be found online:

http://n.neurology.org/subscribers/advertise

Neurology ${ }^{\circledR}$ is the official journal of the American Academy of Neurology. Published continuously since 1951, it is now a weekly with 48 issues per year. Copyright @ 2019 American Academy of Neurology. All rights reserved. Print ISSN: 0028-3878. Online ISSN: 1526-632X.

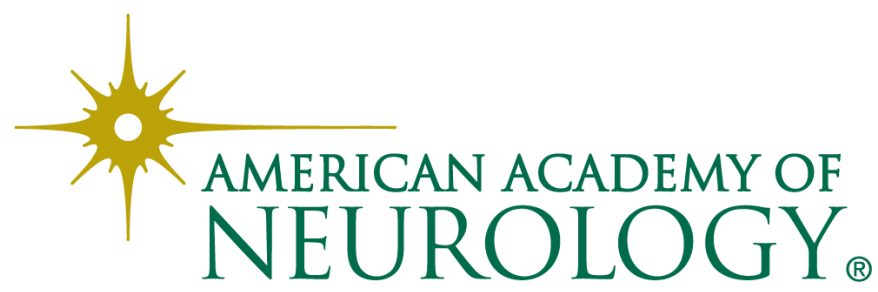

